\title{
What can size distributions within cohorts tell us about ecological processes in fish larvae?
}

\author{
ARILD FOLKVORD ${ }^{1}, \varnothing$ YVIND FIKSEN ${ }^{1}$, HANS HØIE ${ }^{1,2}$, ARNE JOHANNESSEN ${ }^{1}$, \\ ERLING OTTERLEI ${ }^{1,3}$ and KNUT WIIK VOLLSET ${ }^{1}$ \\ ${ }^{1}$ Department of Biology, University of Bergen, N-5020 Bergen, Norway. E-mail: arild.folkvord@bio.uib.no \\ ${ }^{2}$ Institute of Marine Research, P.O. Box 1870, Nordnes N-5817 Bergen, Norway. \\ ${ }^{3}$ Sagafjord Sea Farm A/S, N-5411 Stord, Norway.
}

\begin{abstract}
SUMMARY: Marine fish larvae are subject to variable environments, which is probably reflected in their growth and survival rates. Mortality rates are generally high and size-dependent. At the species level, these mortality rates are usually accompanied by correspondingly high growth rates. Here we provide examples from experimental studies with Atlantic cod (Gadus morhua) and Atlantic herring (Clupea harengus) larvae, in which multiple cohorts were followed over time. Body size, prey concentrations, and temperature are shown to influence growth rates. We present a method based on cumulative size distributions (CSDs) for visualizing variability of sizes within cohorts over time. Analysis of CSDs revealed sizeselective mortality and variations among populations in size- and temperature-dependent growth throughout ontogeny. We found that cod larvae consistently exhibit higher growth rates than herring larvae. While cod larvae may have an advantage over herring larvae when food availability is high, herring were more able to survive at low food concentrations than cod. Cod and herring seem to represent two growth strategies: cod larvae are relatively small at hatching and a high growth rate appears to be a prerequisite for success, whereas herring larvae are initially large, but grow more slowly.
\end{abstract}

Keywords: growth strategies, life history, mortality, prey concentration, size distribution, temperature, trade-off.

RESUMEN: ¿QUÉ PUEDEN DECIRNOS LAS DISTRIBUCIONES DE TALLA DENTRO DE COHORTES SOBRE LOS PROCESOS ECOLÓGICOS EN LARVAS DE PECES? - Las larvas de peces marinos están sujetas a ambientes variables que probablemente se reflejan en sus tasas de crecimiento y supervivencia. Las tasas de mortalidad son generalmente altas y dependientes de la talla. A nivel de especies, estas tasas de mortalidad están usualmente acompañadas de tasas de crecimiento altas. En este trabajo mostramos ejemplos a partir de estudios experimentales con larvas de bacalao atlántico (Gadus morhua) y arenque atlántico (Clupea harengus), en los que se siguieron cohortes múltiples a lo largo del tiempo. Se muestra como la talla del cuerpo, la concentración de presas y la temperatura influyen en la tasa de crecimiento. Presentamos un método basado en distribuciones de frecuencias de talla acumuladas (DTAs) para visualizar la variabilidad en tallas dentro de las cohortes a lo largo del tiempo. El análisis de DTAs reveló mortalidad selectiva por talla, y variaciones entre poblaciones en el crecimiento dependiente de la talla y la temperatura a través de la ontogenia. Encontramos que las larvas de bacalao mostraron consistentemente mayores tasas de crecimiento que las de arenque. Mientras las larvas de bacalao pueden tener una ventaja sobre las de arenque cuando la disponibilidad de presas es alta, las de arenque son más capaces de sobrevivir a bajas concentraciones de comida. Bacalao y arenque parecen representar dos estrategias de crecimiento; las larvas de bacalao son relativamente pequeñas a la eclosión y una alta tasa de crecimiento parece un prerrequisito para el éxito, mientras que las de arenque son inicialmente más largas, pero crecen más lentamente.

Palabras clave: estrategias de crecimiento, ciclo de vida, mortalidad, concentración de presas, distribución de tallas, temperatura, compensación. 


\section{INTRODUCTION}

The larvae of many marine fish species are subject to high and variable mortality and growth rates (McGurk, 1986). At the species level, mortality is generally correlated with growth rates, which possibly reflects the effect of temperature on these vital rates (Houde, 1989). Both rates normally depend on size, age, or stage in a general way, but the actual forms of these relationships are poorly known for most species and populations (Houde, 1997). Mortality rates generally decline with increasing size and age, but this pattern can be modified depending on the spatiotemporal overlap with predators (Litvak and Leggett, 1992; Scharf et al., 2002). Predation in the early life stages of marine fish larvae is well documented as an important source of mortality (Bailey and Houde, 1989; Takasuka et al., 2004), and can be expected to influence the life-history strategies of fish, including the growth and behaviour of larvae (Fiksen et al., 2007). In general, the foraging activity of larvae is likely to elevate the risk of predation due to increased encounters with predators, as well as reduced larval vigilance and evasion ability (Fuiman and Magurran, 1994; Lankford et al., 2001). These trade-offs change during the early life stages as larvae increase in size, sensory function and locomotory performance (Billerbeck et al., 2001; Skajaa et al., 2003). However, starvation resistance in fish larvae does not change much during the larval stage (Hunter and Coyne, 1982; Jordaan and Brown, 2003). The fact that body mass may multiply a hundred fold during the larval stage without any improvement in the ability to resist starvation suggests a trade-off between storage and growth, where growth rate is more important than starvation resistance. This trade-off suggests that predation, which tends to decrease with fish size (McGurk, 1986; Bailey and Houde, 1989), is a driving force in the growth strategies of fish larvae.

The growth potential of a species, defined here as the maximum growth rate at a given body size and temperature when food is supplied in excess, is a result of evolutionary trade-offs where high and low growth rates have different costs and benefits for survival under different environmental conditions. We have developed an empirical size- and temperature-dependent growth (STDG) model for cod (Gadus morhua) and herring (Clupea harengus) larvae (Folkvord, 2005; Fiksen and Folkvord, 1999) based on laboratory experiments with larvae fed in excess. In an individual- based modelling context, growth potential defines the limit of individual growth rates under different feeding conditions (Fiksen and Folkvord, 1999; Kristiansen et al., 2007) or behavioural strategies (Vikeb $\varnothing$ et al., 2007; Kristiansen et al., 2009). Given an initial size-distribution and temperature history, observed growth, exhibited as size-at-age, can be compared with size-at-age patterns predicted by models of growth potential. The degree to which an individual is growing relative to its growth potential we hereafter term "growth performance". It remains a significant challenge to determine the actual growth performance of larvae in nature relative to their growth potential (Folkvord, 2005).

In this paper we present a method based on cumulative size distributions (CSDs), in which the sizes-at-age between repeated samplings of the same cohort can be compared in a single graph. We provide several examples, using cohorts of cod and herring larvae from laboratory studies, to illustrate the importance of environmental factors, such as temperature and food concentration, in observed size-at-age patterns. We then provide examples from two mesocosm studies on cod (Folkvord et al., 1994; Vollset et al., 2009), in which the growth performance can be assessed by comparing observed growth patterns with those estimated from a STDG model. Finally, we comment on the possible adaptive value of the observed differences in growth strategies displayed by cod and herring.

\section{MATERIALS AND METHODS}

\section{Laboratory experiments}

The laboratory data used in this paper are from two multifactorial experiments on cod and herring larvae carried out at the University of Bergen. Both experiments involved a cohort of larvae hatched within a single day (their ages are reported here as days post hatch, $\mathrm{dph}$ ), and which originated from multiparental crossings (strip spawning of one female and six male herring; group spawning of 18 female and 10 male cod). The eggs were incubated at 6 to $7^{\circ} \mathrm{C}$. All larvae were reared in $1 \mathrm{~m}^{2}$ square tanks, with an effective rearing volume of 300 to 5001 . Natural live, size-fractioned zooplankton, mainly copepods, were used as prey and nominal prey concentrations were adjusted daily (Table 1). More details on rearing procedures are described in Otterlei et al. (1999) and Folkvord et al. (2000). 
TABLE 1. - Overview of laboratory experiments with cod and herring larvae. All larvae were reared in $500 \mathrm{~L}$ tanks under a natural spring photoperiod $\left(60^{\circ} \mathrm{N}\right)$ and at temperatures of either 6 or $10^{\circ} \mathrm{C}$. Live natural zooplankton with an initial (and subsequently increasing) size range from 80 to $250 \mu \mathrm{m}$ were used as the food source. The duration of the experiments was 56 days $\left(70\right.$ for cod at $\left.6^{\circ} \mathrm{C}\right)$ and sampling was carried out on a weekly basis. Daily mortality rate is given as the average proportion that died per day (sampling excluded).

\begin{tabular}{lcc}
\hline & Cod & Herring \\
\hline Prey concentrations & 1000,250 and 50 prey $\mathrm{L}^{-1} *$ & 1200 and 40 prey $\mathrm{L}^{-1}$ \\
& & $0.002-0.008$ at $6^{\circ} \mathrm{C}$ \\
Daily mortality rate (M) & $0.006-0.030$ at $6^{\circ} \mathrm{C}$ & $0.004-0.012$ at $10^{\circ} \mathrm{C}$ \\
(High and low prey concentrations) & $0.020-0.062$ at $10^{\circ} \mathrm{C}$ & $65.8-91.2 \%$ at $6^{\circ} \mathrm{C}$ \\
Total survival (\%) $* *$ & $18.3-73.1 \%$ at $6^{\circ} \mathrm{C}$ & $50.4-80.0 \%$ at $10^{\circ} \mathrm{C}$ \\
\hline
\end{tabular}

* decreased from 2000, 750, 200 prey $\mathrm{L}^{-1}$ after $14 \mathrm{dph}$,

** estimated to $56 \mathrm{dph}$ for all groups.

The experiments utilised two temperatures ( 6 and $10^{\circ} \mathrm{C}$ ) and two (herring) or three (cod) prey concentrations: high (1000 to 2000 prey $\left.\mathrm{l}^{-1}\right)$, medium $(250$ to 750 prey $^{1^{-1}}$ ) and low $\left(20\right.$ to 200 prey $\left.1^{-1}\right)$ (Table 1$)$. All treatments were duplicated. Samples of 15 (cod) or 20 (herring) larvae from each tank were taken weekly, starting on $7 \mathrm{dph}$. Larvae remaining at the end of the experiments, $56 \mathrm{dph}\left(70 \mathrm{dph}\right.$ in the $6^{\circ} \mathrm{C}$ cod groups), were counted and the final survival was corrected for the amount and timing of sampling, assuming a constant daily mortality rate.

Live larvae were measured (standard length, $S L$ ) under a stereo microscope and shock frozen in liquid nitrogen before being transferred in individual vials to an ultra-freezer $\left(-80^{\circ} \mathrm{C}\right)$. Dry weight $(D W)$ of individual larvae was measured to the nearest $\mu \mathrm{g}$ after freeze drying (herring) or heating at $60^{\circ} \mathrm{C}$ for at least $24 \mathrm{~h}$ (cod). Between 30 and 40 larvae per treatment were generally measured for $S L$ and at least 26 (cod) and 10 (herring) larvae were measured for $D W$. Due to the relatively low number of $D W$ measurements of herring larvae, the CSDs for this species were based on the $S L$. In the herring experiment only two larvae remained in the $10^{\circ} \mathrm{C}$ low prey density group on $49 \mathrm{dph}$, so these data were excluded from the analysis.

\section{Cumulative size distributions - CSDs}

Presenting population size-at-age by CSDs has an advantage over the typical portrayal of size distributions because CSDs can be plotted on the same graph with minimal overlap and crossing of lines (Fig. 1a, b). When cohorts are repeatedly measured and their lengths plotted on an arithmetic scale (e.g. $S L$ in $\mathrm{mm}$, Fig. 1b), the distance, $\Delta S L$, between the CSDs at any frequency (representing percentile or proportion of population) represents the absolute growth between sampling periods. The daily length growth rate can be estimated by dividing $\Delta S L$ by the number of days between samples. A similar procedure applied to CSDs of log-transformed [log referring to $\log _{\mathrm{e}}$ (natural $\log$ ) throughout the paper] sizes $(S L$ or $D W$ ) on the x-axis, yields the specific growth rate, e.g. $\mathrm{SGR}=\left(\log D W_{\mathrm{t} 2}-\log D W_{\mathrm{t} 1}\right) /(\mathrm{t} 2-\mathrm{t} 1)($ Fig. 1c). The assumption that comparisons can be made across percentiles is based on the observation from several studies that the size ranking of an individual in a population is unlikely to change much in the short term (Rosenberg and Haugen, 1982; Chambers and Miller, 1995; Folkvord et al., 2000). Assuming a static ranking of fish sizes within a cohort, we estimated the growth of all size classes by following the size of a given percentile of the population from one sampling to the next. This will generally lead to a much better estimate of individual larval growth than comparing the sampled size of an individual against the mean (or median) size of the cohort from a previous sampling (Folkvord et al., 1994, Fig. 1d). With sampling intervals kept constant, growth can be easily compared across the entire sampling period. The CSDs of larval sizes from the experiments analysed in this study were generated by combining data from both replicates in order to display the data at the treatment level. CSDs were then plotted against age for the respective treatment groups.

\section{Growth potential and growth performance}

Simulations of larval growth potential in cod were based on the relationship for Norwegian coastal cod presented in Folkvord (2005): $S G R_{\mathrm{NCC}}=1.20+$ $1.80 * T-0.078 * T * \log D W-0.0946 * T^{*}(\log D W)^{2}+$ $0.0105^{*} T^{*}(\log D W)^{3}$, where $T$ is temperature $\left({ }^{\circ} \mathrm{C}\right)$, $D W$ is dry weight (mg), and $S G R$ is specific growth rate $\left(\%\right.$ day $\left.^{-1}\right)$. This STDG model was originally 



FIG. 1. - Size distributions; a) size-frequency distribution of a cohort at three ages (labelled 1 to 3), b) cumulative size distributions (CSDs), c) CSDs on a $\log \mathrm{x}$-scale, d) illustration of growth of small (S), median (M) and large (L) individuals estimated from similar previous CSDs, assuming static size ranking within the cohort over time (solid arrows) and as estimated from an average (median) size in the previous sample (dashed arrows).

based on average sizes-at-age. In order to further develop the STDG model based on average sizes, the effect of individual size variability was simulated by using 1000 individuals with the initial $D W$ (at $7 \mathrm{dph})$ as a random variable $(0.045 \pm 0.0067 \mathrm{mg})$. Sets of these individuals from different temperatures and with different parameter values for the initial size variability were followed until $56 \mathrm{dph}$ using the STDG model. The results of these simulations are presented as CSDs at 7-day intervals and provide a baseline from which to compare observed experimental data.

Growth performance as depicted from CSDs was evaluated for two cohorts from two mesocosm studies: a study of Norwegian coastal cod larvae (Folkvord et al., 1994), and a study of Northeast Arctic cod larvae (Vollset et al., 2009). For the mesocosm larvae, observed initial sizes were used as input for the simulation for the first sampling interval. The simulated CSD was then contrasted with the observed CSD of the following sampling. This observed CSD was then used as the initial CSD for the next sampling period, and so on. The oldest cohort of Norwegian coastal cod described in Folkvord et al., (1994) was originated in a $63000 \mathrm{~m}^{3}$ mesocosm and was followed at 4-day intervals based on day-time sampling for all except the last sampling date, which was carried out late in the evening. Temperature at $4 \mathrm{~m}$ depth was used in the model and was estimated as: $\mathrm{T}=6.6+0.1 * \mathrm{dph}\left(\mathrm{R}^{2}=0.988\right)$. All the larvae from the mesocosm study were preserved in $10 \%$ formalin prior to measurement, but no correction was made since they had all been treated similarly. In the mesocosm study by Vollset et al., (2009), the average temperature in the mesocosms was estimated by the equation: $\mathrm{T}=7.66+0.053^{*}$ dph $\left(R^{2}=0.730\right)$. In this study, weekly samples of the oldest cohort of Northeast Arctic cod larvae were used, and all the larvae from four $2.5 \mathrm{~m}^{3}$ mesocosms were combined. All the larvae were individually fro- 

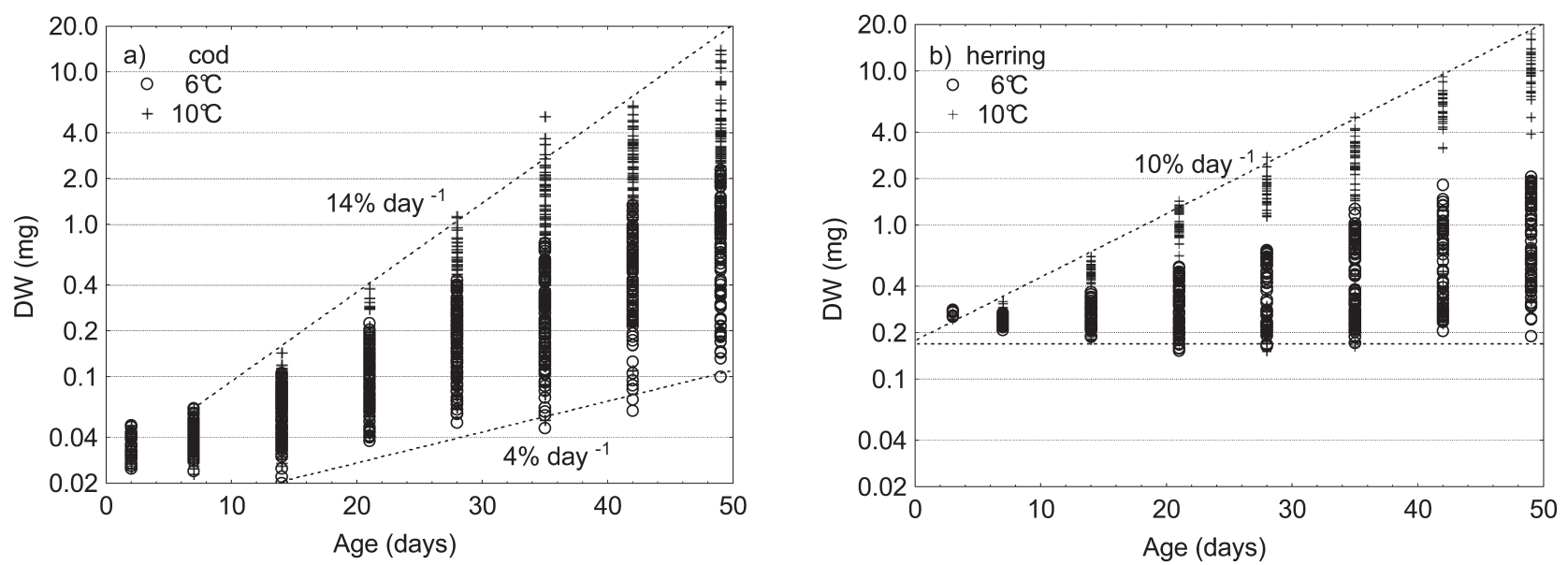

Fig. 2. - Size-at-age of fed a) cod and b) herring larvae from lab experiments at $6{ }^{\circ} \mathrm{C}(-)$ and $10^{\circ} \mathrm{C}(+)$ treatments. Dashed lines were drawn by eye to indicate approximate growth rates of the largest and smallest individuals from different sampling dates (excluding yolk-sac period). Only data until $49 \mathrm{dph}$ are shown in order to include data from all groups throughout the experiments.

zen and subsequently weighed without any weight correction factor. For these data the growth relationship for Northeast Arctic cod was taken as the reference (Folkvord, 2005). The observed CSDs from each sampling period were used as above as initial CSDs for each sequential simulation.

\section{RESULTS}

\section{Lab experiments}

The pattern of variation in size-at-age of larvae was markedly different between cod and herring. Although the herring larvae were on average about four times as heavy at hatch than cod larvae, the size range on $49 \mathrm{dph}$ at 6 and $10^{\circ} \mathrm{C}$ was similar and ranged from 0.1 to nearly $20 \mathrm{mg}$ (Fig. 2). The faster growth of cod than herring at comparable temperatures was evident in all sizes of individuals in the population. The largest cod had an overall average $D W$ growth rate of $\sim 14 \%$ day $^{-1}$ compared to $10 \%$ day $^{-1}$ in herring. The smallest cod to survive to 49 dph grew at $\sim 4 \%$ day $^{-1}(D W)$, while the smallest herring still alive on $49 \mathrm{dph}$ showed no increase in $D W$ after $0 \mathrm{dph}$ (Fig. 2).

\section{CSD - simulated data}

Simulations based on the growth equation from Folkvord (2005) resulted in a series of near-parallel CSDs at different ages (Fig. 3a). Larval growth during the period between samplings of the simulation can be inferred from the distance between the CSDs in the intervening period. By visual inspection alone we can see that maximum growth occurs between 21 and $35 \mathrm{dph}$ (dashed lines) at a size of $\sim 0.7 \mathrm{mg}$ $D W$ (arrow in Fig. 3a). The growth of the larger size classes of the population from 7 to $14 \mathrm{dph}$ was greater than that of the smaller size classes (dashed lines, Fig. 3a), reflecting the increasing growth rate with size during this interval. The higher growth rates of the smaller size classes of the population from 42 to $49 \mathrm{dph}$ reflect the declining growth rate with size during this interval (dashed lines, Fig. 3a). The effect of initial size variation on the CSDs is a change in the steepness of the curves (dashed lines, Fig. 3b). An increase in size variation results in a broadening of the CSDs with a maximal dispersion at $\sim 28 \mathrm{dph}$, eventually declining thereafter. A change in temperature regimes results in shifts in the CSDs. For example, in the $10^{\circ} \mathrm{C}$ group, the CSDs are initially shifted to the right (representing larger sizes-at-age) compared with the CSDs of the 5 to $15^{\circ} \mathrm{C}$ group, due to the higher initial temperature (Fig. 3c). By $56 \mathrm{dph}$, and after a period of similar average temperatures, the CSDs of the two groups overlapped.

\section{Observed CSDs from laboratory studies}

The CSDs of cod and herring larvae from the laboratory experiments further illustrate details of the growth dynamics. For cod larvae at $10^{\circ} \mathrm{C}$ and high prey concentrations, increasing variation in size-at-age is apparent in the flattening of the CSDs for older larvae (Fig. 4a). In contrast to the expected increase in growth rate from 14 to $21 \mathrm{dph}$ (Fig. 3a), a reduction in growth rate in this period can be seen across the entire size range. This reduction in growth coincides with the reduction in 

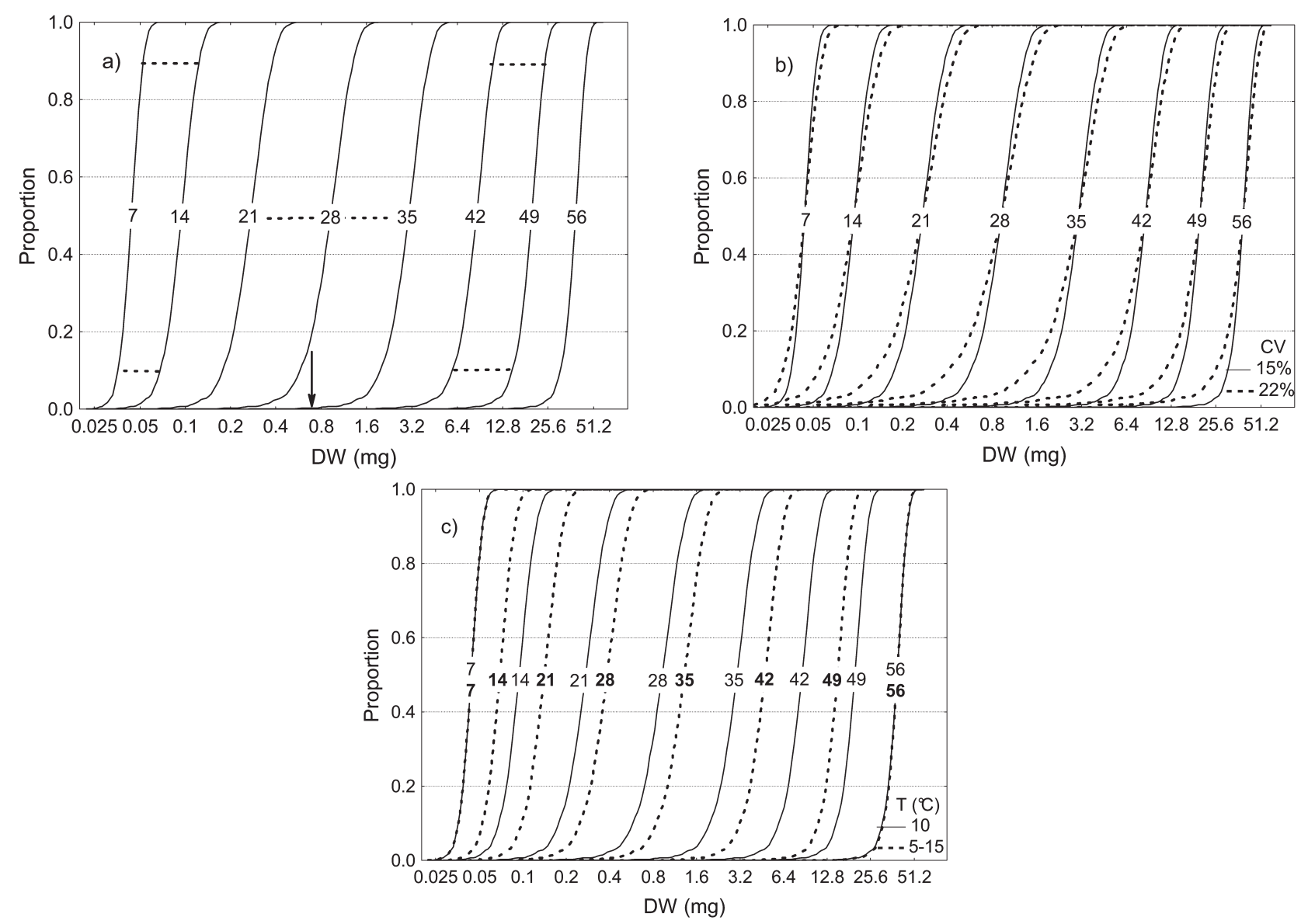

FIG. 3. - Simulated CSDs based on the STDG model by Folkvord (2005); 1000 individuals with average $D W_{7}=0.045 \mathrm{mg}$ and a) initial CV $=15 \%$ and temperature $=10^{\circ} \mathrm{C}$. Horizontal dashed lines represent approximate growth for different parts of the cohort between weekly samplings, the arrow indicates size of maximum growth potential (Folkvord 2005), b) as left with initial CV $=22 \%$ (dashed line), c) temperature linearly increasing from 5 to $15^{\circ} \mathrm{C}$ (dashed line). CSDs in a) shown by solid line in b) and c) for comparison. Numbers on CSDs represent larval age (dph).

prey density from 2000 to 1000 prey $\mathrm{l}^{-1}$, which took place at $14 \mathrm{dph}$. A further reduction in growth rates below the expected values (Fig. 3a), was observed in larvae older than $35 \mathrm{dph}$. The growth rate of the cod larvae in this study is markedly lower than in a previous study of cod reared at $10^{\circ} \mathrm{C}$ with prey available in excess (Otterlei et al., 1999) (Fig. 4b), where the CSDs were nearly parallel, except for larvae at $14 \mathrm{dph}$. Their larvae exhibited noticeably more size variation than at other ages (Fig. 4b). Smaller individuals appeared to have grown more slowly than larger individuals from 7 to $14 \mathrm{dph}$, and the reduced growth rate seems to be compensated for from 14 to $21 \mathrm{dph}$ (Fig. 4b). However, this later increase in growth rate of the smaller individuals contrasts with the pattern observed in larger individuals (Fig. 3a), and is probably partly caused by selective removal (mortality) of the smaller individuals between 14 and $21 \mathrm{dph}$. This time-period coincides with the period of starvation mortality of food-restricted cod larvae. Incorporating a simple representation of size-selective mortality into the simulation (removal of the $30 \%$ smallest individuals) illustrates this point. The CSD at $14 \mathrm{dph}$ for the population with size-selective mortality is generated by recalculating the CSD at this age (dashed line, Fig. 4b). Assuming that the removal of smaller individuals is appropriate, growth between 14 and $21 \mathrm{dph}$ now seems relatively uniform across the size range, as is the case for the rest of the experimental period. This suggests that a significant mortality event with consequences for cohort size structure occurred between 14 and $21 \mathrm{dph}$. In contrast, the CSDs for herring at $10^{\circ} \mathrm{C}$ and high prey concentration show a uniform $S L$ growth in the first two weeks after first-feeding, which indicates that start-feeding was successful in this group (Fig. 4c). Indeed, the final survival of larval herring in this group when corrected for sampling was $80 \%$ at 56 dph (Table 1). A small reduction in growth in the herring larvae was evident between 28 and $35 \mathrm{dph}$. Apart from the CSD at this age, the growth rate of 

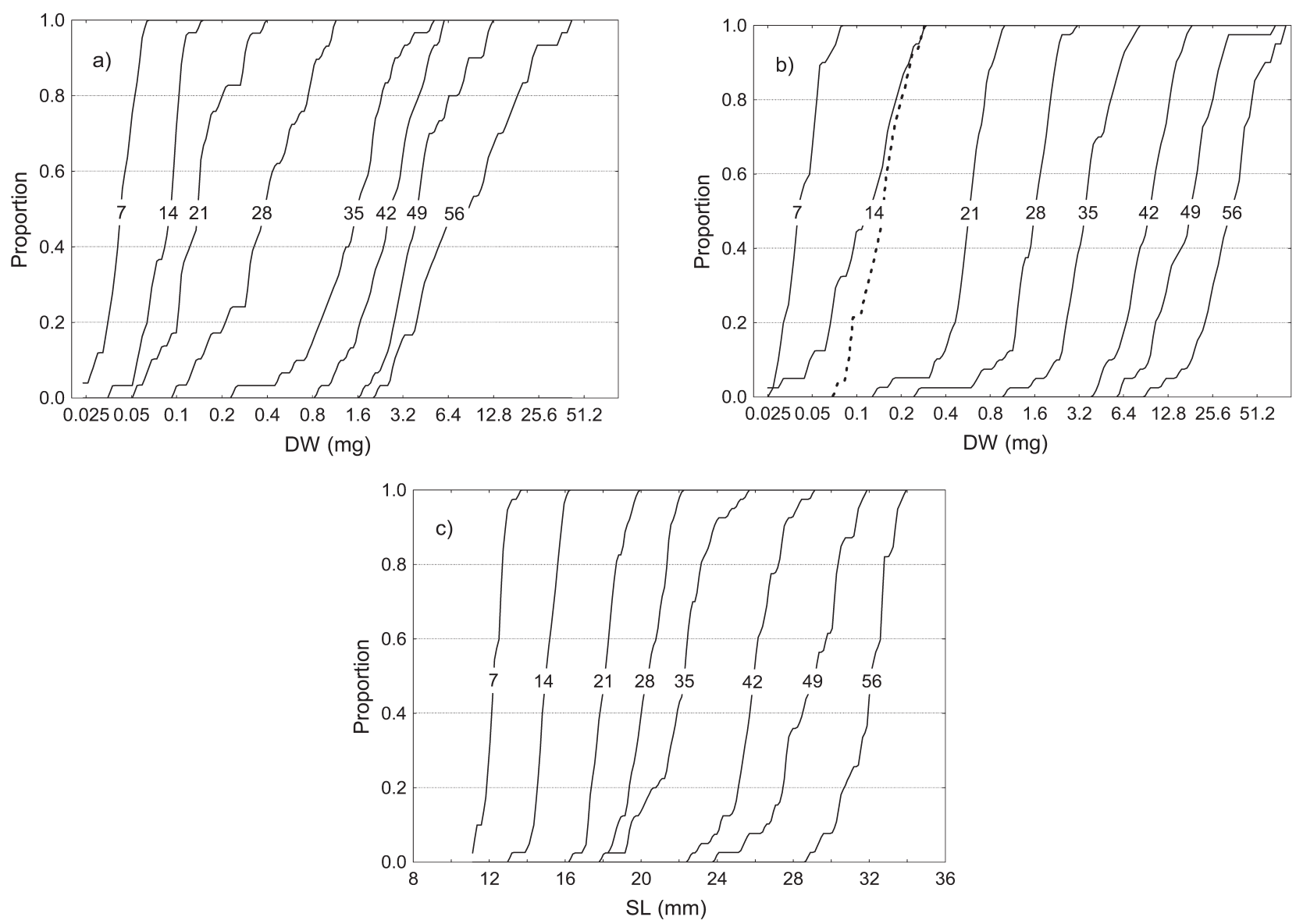

Fig. 4. - Observed CSDs ( $D W$ or $S L$ ) from laboratory experiments sampled weekly with a) cod at $10^{\circ} \mathrm{C}$ and high prey concentration (this study), b) cod at $10^{\circ} \mathrm{C}$ and high prey concentration (Otterlei et al., 1999); dashed line represents the recalculated CSD after removing the smallest $30 \%$ of individuals on $14 \mathrm{dph}, \mathrm{c}$ ) herring at $10^{\circ} \mathrm{C}$ and high prey concentration (this study). Numbers on CSDs represent larval age (dph).

the herring seems to be constant over time, and uniform between size classes.

CSDs can also be used for interspecific comparisons of larval growth potential in different environments. Cod larvae offered different prey concentrations soon exhibited different average sizes-at-age, but size variability within groups was not affected (Fig. 5a). In this case, the CSDs suggest that the reduction in the availability of prey did not generate size-dependent mortality. The CSD at $35 \mathrm{dph}$ in the high prey concentration group was markedly shifted towards larger sizes relative to that of the low prey group, but by $56 \mathrm{dph}$, when few individuals were left in the low prey concentration tanks (Table 1), the CSDs were more similar. On the other hand, a higher ambient temperature for cod larvae eventually resulted in higher size variability in addition to higher average growth (Fig. 5b). The average size of larvae in the $6^{\circ} \mathrm{C}$ high prey concentration group by $70 \mathrm{dph}$ was similar to that at $56 \mathrm{dph}$ in the $10^{\circ} \mathrm{C}$ high prey group, but with lower size variability in the $6^{\circ} \mathrm{C}$ group despite the initial sizes and size variability being similar at $21 \mathrm{dph}$. In herring there was no apparent increase in size variability with increasing temperature. As shown previously, the herring larvae in the low prey group hardly grew at all, while no marked differences in size variability was observed relative to the larvae from the high prey group (Fig. 5c). Finally, larvae from the $10^{\circ} \mathrm{C}$ high prey concentration group on $35 \mathrm{dph}$ had a similar CSD to larvae from the $6^{\circ} \mathrm{C}$ high prey concentration group by $56 \mathrm{dph}$ (Fig. $5 \mathrm{c}$ ). In summary, the CSDs revealed that in cod, in contrast to herring, size variability increased with increasing temperature, while the effect of higher prey concentrations manifested itself primarily as a increase in average cohort growth within each species.

\section{Evaluation of growth performance in mesocosm studies}

The two mesocosm studies (Folkvord et al., 1994; Vollset et al., 2009) differed in their degree 



FIG. 5. - Observed CSDs ( $D W$ or $S L)$ from laboratory experiments with a) cod at $10^{\circ} \mathrm{C}$ and low prey concentration (solid lines) and high prey concentration (dashed lines), b) cod at high prey concentration and $6^{\circ} \mathrm{C}$ (solid lines) and $10^{\circ} \mathrm{C}$ (dashed lines), c) herring at $10^{\circ} \mathrm{C}$ and low prey concentration (solid lines) and high prey concentration (dashed lines), and d) herring at high prey concentration and $6^{\circ} \mathrm{C}$ (solid lines) and $10^{\circ} \mathrm{C}$ (dashed lines). Numbers on CSDs represent larval age (dph).
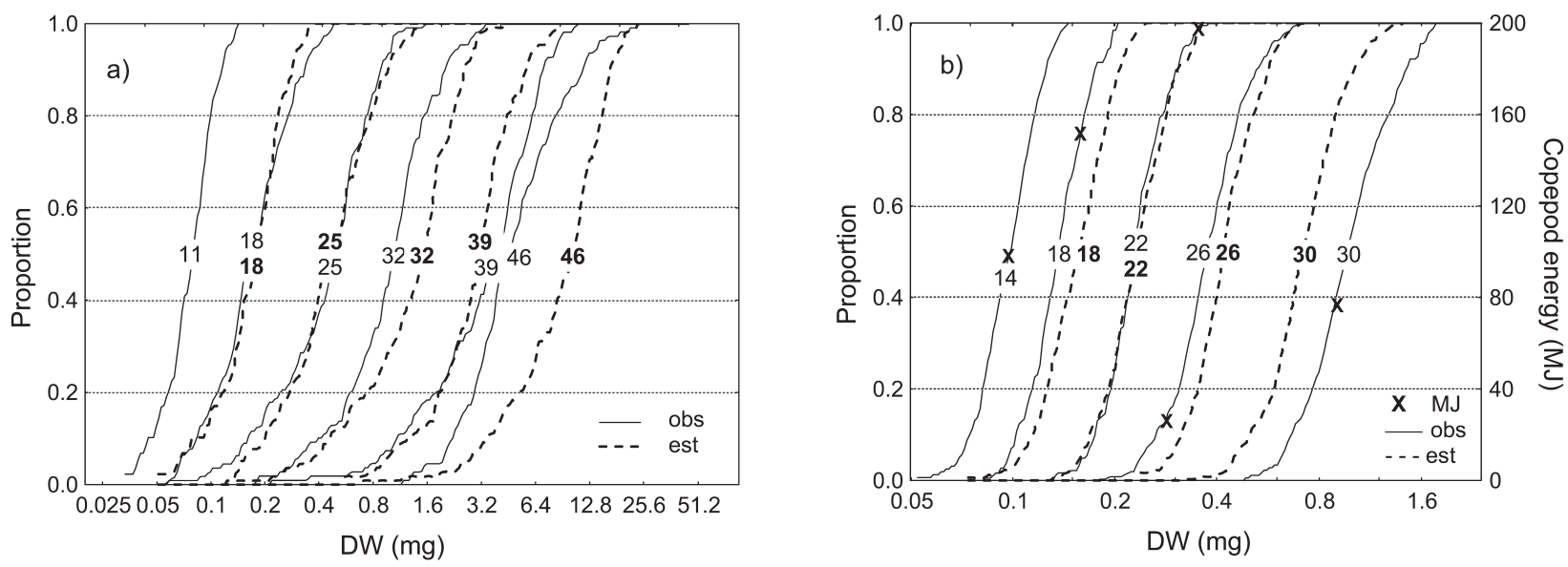

FIG. 6. - Observed (solid lines) and estimated (dashed lines) CSDs $(D W)$ from mesocosm experiments with cod from a) Vollset et al., (2009), b) Folkvord et al., (1994). Estimated values are based on the STDG model from Folkvord (2005). Crosses represent average copepod energy (MJ) available for different time periods in the respective CSDs in b). Observed weight distributions at 11 dph (a) and 14 dph (b) are used as the initial CSD for model estimations, and subsequent observed CSDs are used as inputs for estimating the sizes on the next sample date.

of correspondence with the size estimated from simulations, suggesting that growth of larvae was food limited at some stage. In the mesocosm experi- ment by Vollset et al. (2009), the observed CSDs at $\leq 25 \mathrm{dph}$ were similar to those estimated by the model (Fig. 6a). Towards the end of the experiment 
(46 dph) when prey abundance was a limiting factor, growth performance was generally low, although some large specimens were growing at their sizeand temperature-dependent potential. These cod had possibly overcome the limitation in food availability by becoming cannibals (Seljeset et al., in press). In the other mesocosm experiment (Folkvord et al., 1994), the observed growth rates lagged behind the estimated temperature-limited growth by $18 \mathrm{dph}$, suggesting that food was a limiting factor (Fig. 6b). In the following period $(22 \mathrm{dph})$ when the available food (copepod) energy in the mesocosm peaked at 200 MJ (Folkvord et al., 1994), the observed growth rate was similar to the growth potential. A subsequent decrease in available food energy in the pond resulted in poorer growth performance. The growth rate increased again towards the final sampling period $(30 \mathrm{dph})$ when the available food energy had more than doubled (Fig. 6b). Presenting cohort data as CSDs, and comparing them to estimates of CSDs when food is not limiting, enabled us to detect when the cohorts experience sub-optimal conditions.

\section{DISCUSSION}

Cod and herring larvae in these experiments showed clear differences in their patterns of growth and mortality. Herring survived better than cod over a wide range of rearing temperatures and prey concentrations. Cod had higher maximum growth rates and higher minimum growth rates than herring larvae over the range in temperatures employed. Unlike cod, herring seem to prioritize survival over maximizing growth. These findings are in accordance with previous studies in which herring larvae had exceptionally high survival rates in outdoor enclosures (e.g. $70 \%$ until $130 \mathrm{dph}$, yielding an average daily mortality rate of only 0.003, Øiestad and Moksness, 1981). Previous laboratory studies with herring larvae have also reported very low mortality rates $(0.008$ per day, Pedersen, 1993). To the best of our knowledge, no studies have reported mortality rates as low as those reported here $\left(0.002\right.$ per day over $56 \mathrm{dph}, 6^{\circ} \mathrm{C}$ group at high prey concentration). In terms of growth, the few cod larvae in the low prey concentration group at $10^{\circ} \mathrm{C}$ that survived until the termination of the experiment were nearly as large as those from the high prey concentration group, even though their growth rates were lower earlier on. This is in line with the findings of Folkvord (2005), in which the surviving cod larvae and early ju- veniles in the field were characterized by high growth rates in spite of suboptimal growth of younger cod larvae being documented from one of the same areas (Buckley et al., 2004). This was in part attributed to selective mortality of smaller, slower growing cod larvae, which has been documented in the field (Meekan and Fortier, 1996; Nielsen and Munk, 2004) and in experiments (Folkvord et al., 1994; Koedijk et al., accepted). Thus, for a cohort of cod larvae, the quality of their feeding conditions is likely to be reflected in their survival as well as their growth rates.

Presenting successive CSDs from experimental studies of larval fish cohorts appears to be quite useful. Here, we have shown that the CSDs can be useful in revealing growth differences and size-dependent mortality (Fig. 4) when we compare experimental treatment effects within cohorts (Fig. 5) and contrast observed versus estimated responses in simulated populations (Fig. 6). The CSDs reveal patterns and allow rapid visualization of the size structure of the cohort over time, especially when the sampling interval is constant. CSDs have previously been used to infer size-selective cannibalism in juvenile cod (Folkvord and Otterå, 1993). The study found that the presence of cannibalistic siblings twice as long as the remaining fish resulted in the selective removal of smaller individuals and a reduction in the growth of non-cannibals relative to same-sized conspecifics in tanks without cannibals. In the CSDs, the effect of cannibalism was apparent as a shift towards larger sizes of the smaller size classes in the groups with higher cannibalism rates, as well as a shift towards smaller sizes of the larger non-cannibals. Baumann et al. (2008) used length CSDs to assess differences in size-at-date of sprat within and between years and, similarly to this study, the CSDs clearly revealed differences in size distribution between groups of fish from different environments. Their samples consisted of fish of different ages, and a direct comparison of growth between different size proportions (percentiles) of the populations was not attempted. Clearly the use of cohort data is simpler in an experimental setting, but cohorts of larvae in nature can be tracked for long periods by a combination of hydrodynamic particle tracking models, adequately spatially and temporally resolved sampling, and otolith microstructure analysis (Heath and Gallego, 1997; Gallego and Heath, 1997). We therefore expect an increased use of CSDs in combination with STDG models to further enhance the understanding of larval population dynamics in the sea. 
Size variability may be of great importance for the survival of a cohort in the sea, as it represents what selective mortality works on. In our experiments with herring larvae, a clear temperature effect on average size-at-age was found without any noticeable effects on size variability. The CSD of the $6^{\circ} \mathrm{C}$ high prey concentration group at $56 \mathrm{dph}$ was almost identical to that of the $10^{\circ} \mathrm{C}$ high prey concentration group at $35 \mathrm{dph}$. The 21-day age difference at size was higher in herring than in cod larvae, and the corresponding cod group at $6^{\circ} \mathrm{C}$ was only lagging $\sim 14$ days behind the $10^{\circ} \mathrm{C}$ group at the end of the experiment. At the same time, the size-at-age variability of cod in the $10^{\circ} \mathrm{C}$ group was noticeably higher than in the $6^{\circ} \mathrm{C}$ group. This difference in size variability mainly developed after $14 \mathrm{dph}$ when growth rates started to decline due to a reduction in prey concentration in the tanks. The $6^{\circ} \mathrm{C}$ group, which was not as impacted by the reduction in prey concentration at this stage, presumably due to lower ingestion and metabolic rates (Kristiansen et al., 2007; Finn et al., 2002), had less size variation throughout the experiment. An increase in size variation during periods of intermediate levels of food restriction has been documented in several species (e.g. Jobling and Koskela, 1996), and is not a particular feature of cod larvae. The CSD of the $10^{\circ} \mathrm{C}$ high prey group from Otterlei et al. (1999) also revealed a higher rate of growth and less variation in size-at-age than the corresponding $10^{\circ} \mathrm{C}$ group from this study. Furthermore, the CSD at $56 \mathrm{dph}$ of the $6^{\circ} \mathrm{C}$ group from Otterlei et al. (1999) (not shown here) was, as in our herring example, nearly identical to the CSD of the $10^{\circ} \mathrm{C}$ group from $35 \mathrm{dph}$. Since the final survival to $56 \mathrm{dph}$ was not higher in Otterlei et al. (1999) than reported here (31.8 vs. $33.4 \%$ ), other explanations such as prey size availability may explain the difference in larval size variation between experiments. Even so, we can conclude that for cod the interaction between prey availability and temperature is decisive for the ultimate size variability of a cohort. For herring larvae at low prey concentrations, size variability as well as size-at-age did not change much during the first $35 \mathrm{dph}$ at $10^{\circ} \mathrm{C}$. Due to the limited size range available from the low prey concentration group reported here, we cannot conclude whether or not herring larvae will increase their size variability with age at sub-optimal conditions. An earlier study of herring larvae (Werner and Blaxter, 1980) concluded that size variability was not linked to prey concentration or survival, suggesting that prey availability may have less of an influence on the size variation in a herring cohort compared to a cod cohort. This may partly be due to intracohort agonistic behaviour, which has been observed in cod larvae as small as $6 \mathrm{~mm}$ (Puvanendran et al., 2008). The underlying dynamics of changes in size variability, such as the suppression of growth of the relatively smaller individuals in a cohort, or increased growth of larger more competitive and/or cannibalistic individuals, are readily visible in CSDs.

The utility of CSDs is enhanced when they are combined with size- and temperature-based predictions of growth rate potential, as in the simulations and mesocosm studies used here. In these cases, the comparison of growth across the entire size range observed at a given age, or the entire sampling period, will facilitate a better understanding of growth and mortality dynamics of the population. Reduced growth performance below the inherent size-dependent potential of the various size classes of the population may be detected, and unrealistic apparent growth rates of smaller individuals may indicate periods of size-selective mortality (Otterå, 1992; Tian et al., 2007). In the case of the cod larvae at $10^{\circ} \mathrm{C}$ from Otterlei et al. (1999), the unrealistically high growth estimates of the smaller individuals from 14 to $21 \mathrm{dph}$ indicated that size-selective mortality was occurring. Alternative explanations such as sampling bias and compensatory growth following periods of reduced growth should also be considered (e.g. McGurk, 1992; Bertram et al., 1993). The rapid growth towards the end of the experiment of the cod larvae at $10^{\circ} \mathrm{C}$ and at low prey concentrations may have been partly a compensatory growth response to the previous period of food-limited growth (Jobling and Koskela, 1996).

The differences between cod and herring in their growth and mortality patterns warrant further consideration. The physiology of cod appears to be geared towards maximizing growth. They are vulnerable to starvation if ingestion rates and food supply are low. Cod can be expected to be more vulnerable to predation than herring because they hatch at smaller sizes (McGurk, 1986). This higher predation risk may select for higher growth rates at the expense of acquiring fat reserves that would sustain larvae during periods of food shortages. In contrast, herring larvae are larger at hatching and they grow more slowly than cod, but they are more resistant to starvation. The difference between these two species at the larval stage cannot be fully understood without adopting a full life-cycle 
perspective, as it may reflect a parent-offspring conflict: individual offspring will benefit from being large at hatching, well developed, and with a rich supply of yolk, while parents benefit from producing a large number of smaller offspring in different environments (Winemiller and Rose, 1993). Another source of differences in larval growth patterns is the occasional success of clupeoids that spawn in the autumn. Larvae in autumn-spawned cohorts are thought to experience less food and higher predation than those in springspawned cohorts. The infrequent occurrence of autumn spawning in gadoids probably reflects different constraints in the adult phase of life, but may have consequences for larval growth strategies. Another difference between herring and cod is the transparency and early schooling tendency of herring larvae. Each feature may result in lower predation risk and, consequently, less benefit of high growth rates.

In summary, the CSD approach presented here has great potential for revealing patterns in the growth of species in different environments. Combining this approach with STDG models enables us to analyse deviance from predicted growth, including identifying size-selective mortality. Applying this method to two distinct species has revealed several aspects of the two "growth strategies" that would not have been apparent if summary statistics of traditional analyses of growth had been used.

\section{ACKNOWLEDGEMENTS}

The work was partly funded by the EU projects "Precision and accuracy of tools in recruitment studies" (FAIR-CT96-1371), "Bergen Marine Food Chain Research Infrastructure" (HPRI-CT-199900056) and the Research Council of Norway through a Strategic Research Programme "Environmental influence on fish stocks" (130192/140). The help of Frank Midtøy, Katrine Skajaa, Bob Batty, Innes Stewart and Kristogu Baduge Suneetha during the larval experiments and analyses is greatly appreciated. The paper has benefited significantly from insightful and constructive advice from referees and language corrections by Hugh Allen.

\section{REFERENCES}

Bailey, K.M. and E.D. Houde. - 1989. Predation on eggs and larvae of marine fishes and the recruitment problem. Adv. Mar. Biol., 25: $1-83$.
Baumann, H., R. Voss, H.-H. Hinrichsen, V. Mohrholz, J.O. Schmidt and A. Temming. - 2008. Investigating the selective survival of summer- and spring-born sprat, Sprattus sprattus, in the Baltic Sea. Fish. Res., 91: 1-14.

Bertram, D.F., R.C. Chambers and W.C. Leggett. - 1993. Negative correlations between larval and juvenile growth rates in winter flounder: implications of compensatory growth for variation in size-at-age. Mar. Ecol. Prog. Ser., 96: 209-215.

Billerbeck, J.M., T.E. Lankford and D.O. Conover. - 2001. Evolution of intrinsic growth and energy acquisition rates. I. Tradeoffs with swimming performance in Menidia menidia. Evolution, 55(9): 1863-1872.

Buckley, L.J., E.M. Caldarone and G. Lough. - 2004. Optimum temperature and food-limited growth on larval Atlantic cod (Gadus morhua) and haddock (Melanogrammus aeglefinus) on Georges Bank. Fish. Ocean., 13: 134-140.

Chambers, R.C. and T.J. Miller. - 1995. Evaluating fish growth by means of otolith increment analysis: special properties of individual-level longitudinal data. Secor, In: D.H., Dean, J.M. and Campana, S.E. (eds.). Recent developments in fish otolith research, pp. 155-175. Columbia, SC, University of South Carolina Press.

Fiksen, Ø. and A. Folkvord. - 1999. Modelling growth and ingestion processes in herring Clupea harengus larvae. Mar. Ecol. Prog. Ser., 184: 273-289.

Fiksen, Ø., C. Jørgensen, T. Kristiansen, F. Vikeb $\varnothing$ and G. Huse. - 2007. Linking behavioural ecology and oceanography: larval behaviour determines growth, mortality and dispersal. Mar. Ecol. Prog. Ser., 347: 195-205.

Finn, R.N., I. Rønnestad, T. van der Meeren and H.J. Fyhn. - 2002. Fuel and metabolic scaling during the early life stages of Atlantic cod Gadus morhua. Mar. Ecol. Prog. Ser., 243: 217-234.

Folkvord, A. - 2005. Comparison of size-at-age of larval cod (Gadus morhua L.) from different populations based on sizeand temperature-dependent models. Can. J. Fish. Aquat. Sci., 62: $1037-1052$

Folkvord, A. and H. Otterå. - 1993. Effects of initial size distribution, day length and feeding frequency on growth, survival and cannibalism in juvenile Atlantic cod (Gadus morhua L.). Aquaculture, 114: 243-260.

Folkvord, A., G. Blom, A. Johannessen and E. Moksness. - 2000. Growth dependent age estimation in herring (Clupea harengus L.) larvae. Fish. Res., 46: 91-103.

Folkvord, A., A. Johannessen and E. Moksness. - 2004. Temperature dependent otolith growth in herring (Clupea harengus) larvae. Sarsia, 89(5): 297-310.

Folkvord, A., V. Øiestad and P.G. Kvenseth. - 1994. Growth patterns of three cohorts of Atlantic cod larvae (Gadus morhua L.) studied in a macrocosm. ICES J. Mar. Sci., 51(3): 325-336.

Fuiman, L.A. and A.E. Magurran. - 1994. Development of predator defences in fishes. Rev. Fish Biol. Fish., 4(2): 145-183.

Gallego, A. and M. Heath. - 1997. The effect of growth-dependent mortality, external environment and internal dynamics on larval fish otolith growth: an individual-based modelling approach. $J$. Fish Biol., 51(Suppl. A): 121-134.

Heath, M. and A. Gallego. - 1997. From the biology of the individual to the dynamics of the population: bridging the gap in fish early life studies. J. Fish Biol., 51(Suppl. A): 1-29.

Houde, E.D. - 1989. Comparative growth, mortality and energetics of marine fish larvae: temperature and latitudinal effects. Fish. Bull. U.S., 87(3): 471-495.

Houde, E.D. - 1997. Patterns and trends in larval-stage growth and mortality of teleost fish. J. Fish Biol., 51(Suppl. A): 52-83.

Hunter, J.R. and K.M. Coyne. - 1982. The onset of schooling in northern anchovy larvae, Engraulis mordax. CalCOFI Rep., 23: 246-251.

Jobling, M. and J. Koskela. - 1996. Interindividual variations in feeding and growth in rainbow trout during restricted feeding and in a subsequent period of compensatory growth. J. Fish Biol., 49(4): 658-667.

Jordaan, A. and J.A. Brown. - 2003. The risk of running on empty: the influence of age on starvation and gut fullness in larval Atlantic cod (Gadus morhua). Can. J. Fish. Aquat. Sci., 60(10): 1289-1298.

Koedijk, R., A. Folkvord, A. Foss, K. Pittman, S.O. Stefansson, S. Handeland and A. Imsland. - in press. The influence of first feeding diet on the Atlantic cod phenotype, with emphasis on 
growth, survival, RNA:DNA and long term implications. $J$. Fish Biol.

Kristiansen, T., Ø. Fiksen and A. Folkvord. - 2007. Modelling feeding, growth and habitat selection in larval cod: observations and model predictions in a macrocosm environment. Can. J. Fish. Aquat. Sci., 64: 136-151.

Kristiansen, T., C. Jørgensen, R. G. Lough, F. Vikebø and Ø. Fiksen. -2009 . Trading risk and growth: exploring behavioral rules of larval cod on Georges Bank. Behav. Ecol. 20(3): 490-500.

Lankford, T.E., J.M. Billerbeck and D.O. Conover. - 2001. Evolution of intrinsic growth and energy acquisition rates. II. Tradeoffs with vulnerability to predation in Menidia menidia. Evolution, 55(9): 1873-1881.

Litvak, M.K. and W.C. Leggett. - 1992. Age and size-selective predation on larval fishes: the bigger-is-better hypothesis revisited. Mar. Ecol. Prog. Ser., 81(1): 13-24.

McGurk, M.D. - 1986. Natural mortality of marine pelagic fish eggs and larvae: Role of spatial patchiness. Mar. Ecol. Prog. Ser., 34(3): 227-242.

McGurk, M.D. - 1992. Avoidance of towed plankton nets by herring larvae: a model of night-day catch ratios based on larval length, net speed and mesh width. J. Plankton Res., 14(1): 173-181.

Meekan, M.G. and L. Fortier. - 1996. Selection for fast growth during the larval life of Atlantic cod Gadus morhua on the Scotian Shelf. Mar. Ecol. Prog. Ser., 137: 25-37.

Nielsen, R. and P. Munk. - 2004. Growth pattern and growth dependent mortality of larval and pelagic juvenile North Sea cod Gadus morhua. Mar. Ecol. Prog. Ser., 278: 261-270.

Øiestad, V. and E. Moksness. - 1981. Study of growth and survival of herring larvae (Clupea harengus L.) using plastic bag and concrete basin enclosures. Rapp. P.-verb. Réun. Cons. Int. Explor. Mer, 178: 144-149.

Otterlei, E., G. Nyhammer, A. Folkvord and S.O. Stefansson. 1999. Temperature and size dependent growth of larval and juvenile cod (Gadus morhua L.) - a comparative study between Norwegian coastal cod and Northeast Arctic cod. Can. J. Fish. Aquat. Sci., 56: 2099-2111.

Otterå, H. - 1992. Bias in calculating growth rates in cod (Gadus morhua L.) due to size-selective growth and mortality. J. Fish Biol., 40: 465-467.

Pedersen, B.H. - 1993. Growth and mortality in young herring $(\mathrm{Clu}$ pea harengus); effects of repetitive changes in food availability.
Mar. Biol., 117: 547-550.

Puvanendran, V., B.J. Laurel and J.A. Brown. - 2008. Cannibalism of Atlantic cod Gadus morhua larvae and juveniles on firstweek larvae. Aquat. Biol., 2: 113-118.

Rosenberg, A.A. and A.S. Haugen. - 1982. Individual growth and size-selective mortality of larval turbot, Scophthalmus maximus, reared in enclosures. Mar. Biol., 72: 73-77.

Scharf, F.S., J.A. Buckel and F. Juanes. - 2002. Size-dependent vulnerability of juvenile bay anchovy Anchoa mitchilli to bluefish predation: Does large body size always provide a refuge? Mar. Ecol. Prog. Ser., 233: 241-252.

Seljeset, O., K.W. Vollset, A. Folkvord and A.J. Geffen. - in press. The role of prey concentration and size range in the growth and survival of larval cod. Mar. Biol. Res.

Skajaa, K., A. Fernö A. and A. Folkvord. - 2003. Swimming, feeding and predator avoidance in cod larvae (Gadus morhua L.): trade-offs between hunger and predation risk. In H.I. Browman and A.B. Skiftesvik (eds.). The Big Fish Bang: Proceedings of the 26th Annual Larval Fish Conference, pp. 105-121. Institute of Marine Research, Bergen, Norway.

Takasuka, A., I. Aoki and I. Mitani. - 2004. Three synergistic growth-related mechanisms in the short-term survival of larval Japanese anchovy Engraulis japonicus in Sagami Bay. Mar. Ecol. Prog. Ser., 270: 217-228.

Tian, T., Ø. Fiksen and A. Folkvord. - 2007. Estimating larval fish growth under size-dependent mortality: a numerical analysis of bias. Can. J. Fish. Aquat. Sci., 64: 554-562.

Vikebø, F., C. Jørgensen, T. Kristiansen and Ø. Fiksen. - 2007. Drift, growth, and survival of larval Northeast Arctic cod with simple rules of behaviour. Mar. Ecol. Prog. Ser., 347: 207-219.

Vollset, K.W., O. Seljeset, Ø. Fiksen and A. Folkvord. - 2009. A common garden experiment with larval Northeast Arctic and Norwegian coastal cod cohorts in replicated mesocosms. Deep Sea Res. II, doi:10.1016/j.dsr2.2008.11.009.

Werner, R.G. and J.H.S. Blaxter. - 1980. Growth and survival of larval herring (Clupea harengus) in relation to prey density. Can. J. Fish. Aquat. Sci., 37: 1063-1069.

Winemiller, K.O. and K.A. Rose. - 1993. Why do most fish produce so many tiny offspring. Am. Nat., 142(4): 585-603.

Received November 15, 2008. Accepted July 7, 2009.

Published online October 5, 2009. 